\title{
How to Identify and Assess Risk Factors for Large-scale Running Events: The Organizers' Perspective
}

\author{
Jacek ŁUCZAK ${ }^{1}$, Małgorzata MIŚNIAKIEWICZ² and Jose M. SAAVEDRA ${ }^{3}$ \\ ${ }^{1}$ Poznań University of Economics and Business, Management Institute, Quality Management \\ Department, al. Niepodległości, Poznań, Poland \\ ${ }^{2}$ Cracow University of Economics, College of Management and Quality, \\ Department of Food Product Quality, Krakow, Poland \\ ${ }^{3}$ Physical Activity, Physical Education, Sport and Health (PAPESH) Research Centre, Sports Science \\ Department, School of Social Sciences, Reykjavik University, Reykjavik, Iceland
}

Correspondence Should be Addressed to: Jacek ŁUCZAK; jacek.luczak@ue.poznan.pl

Received Date:21 September 2020; Accepted Date:9 February 2021; Published Date: 1 July 2021

Academic Editor: loana-Alexandra Toader

COPYRIGHT @ 2021. Jacek Łuczak, Małgorzata Miśniakiewicz and Jose M. Saavedra. Distributed Under Creative Commons Attribution 4.0 International Cc-By 4.0

\begin{abstract}
Marathon is one of the fastest growing sports disciplines and it generally boasts a large number of participants from around the world. As the organization and management of largescale running events poses a real challenge, risk evaluation should always precede the decision-making regarding the safety and precautionary measures. The purpose of the research is to identify and assess the risk factors of large-scale running events, taking marathons organized in Poland as an example. Fourteen of the largest marathons held in 2017 in Poland were considered in the study. Fifteen experts were questioned using the Delphi method to carry out the multistage identification of risk factors for the organization of a large-scale run, while 31 practitioners - the representatives of marathon organizing teams - conducted the risk assessment. Considering the effect and likelihood of the appearance of an adverse event, the most important risks turned out to be those related to the financing of marathons, organization issues, including the event start date, the acceptance of the local community, the organization of the finish line, delayed start, cyber security, disclosure of personal data and problems with the measurement of time. The obtained results may serve as reliable input data for the efficient risk management of sporting events (runs in particular). Professional risk management, based on the risk factors database worked out as a result of the research, may become a starting point to provide the highest possible level of safety and satisfaction for all the stakeholders involved in the event.
\end{abstract}

Keywords: Risk Management, Risk Factors for Marathons, ISO 31000, Safety, Satisfaction.

Cite this Article as: Jacek Łuczak, Małgorzata Miśniakiewicz and Jose M. Saavedra (2021)," How to Identify and Assess Risk Factors for Large-scale Running Events: The Organizers' Perspective ", IBIMA Business Review, Vol. 2021 (2021), Article ID 178203, DOI: 10.5171/2021.178203 


\section{Introduction}

Recreational running, as one of the most accessible forms of exercise, is not only a physical activity that serves as a preventive health action, but also a widely practiced sport (Petridis, 2015).

Running started to gain popularity in Poland at the beginning of the 21st century, - whereas, it was already popular in the west in the 1970s.. Approximately, 20\% of the adult population of Poles are now practicing recreational running, which is the highest percentage in Central and Eastern Europe (Poland Runs, National Runners Survey, 2014). Most runners, within less than a year after starting regular training, begin to passively and, eventually, actively participate in mass running events (Dzięgiel \& Lubowiecki-Vikuk, 2013; Petridis, 2015). Interestingly, runners rarely choose to take part in one or two marathons a year. They often participate in a few or even several large-scale running events over the course of a year (Hitchings \& Latham, 2017).

Large-scale running events arouse a lot of emotions and are associated with great expectations of the organizers, participants, spectators and sponsors. Engaging large funds also carries a lot of uncertainty in many organizational aspects (Fuller \& Drawer, 2004; Leopkey \& Parent, 2009). Their complexity results from legal and formal requirements as well as the fact that each event and even each subsequent edition is different, which limits the possibility of using standard solutions. The specificity of a running event also results from the limited possibility to introduce changes during the event, which excludes the improvement of a plan during its implementation. The diversity of the number of participants and their sporting level, as well as the limited time and date of the event should also be taken into account (Scheerder, Breedveld \& Borgers, 2015). All of that explains why the professional management of sporting events is a necessary element to effectively carry out a project, such as organizing a running event.
Participants of marathons, in addition to professional runners, are more often amateurs. An ever-increasing amateur participation in marathons driven by the will to compete with others, test themselves, and experience something new and extreme also creates a certain risk, which is now becoming ever important and hard to control. 'When the person is inexperienced, it is likely that he/she does not understand the potential risk that may be present during the competition' (Miller, Pauline \& Wendt, 2013, p. 18). Accepting the risk of the event may be the result of not knowing the actual levels of risk involved (Fuller \& Drawer, 2004). Therefore, the sporting event managers have a major responsibility towards identifying and managing the risk associated with the running event. Risk management becomes crucial when the participation in a sporting event, such as a long-distance run, requires neither a certain level of experience, nor a medical certificate of good health condition.

Although large-scale sporting event risk management policies have been analyzed and discussed in general, little research has been conducted regarding risk management in running events (Miller, Pauline \& Wendt, 2013; Moyle, Kennelly \& Lamont, 2014). That is why an answer to the following research question has been sought: How can the organizers of running events ensure a safe and satisfying environment for the participants (mostly amateurs) and manage the risk for a longdistance running event professionally. The long-term goal of the research is to add the knowledge about practical aspects of risk management to the evolving industry of large-scale running events in Central and Eastern Europe, so that the records of risk identified by the experts and verified by the practitioners could be mitigated and controlled.

\section{Research problem in the context of literature}

Risk can be treated as a threat of 'any future incident that will negatively influence the event' (Bowdin et al., 2006, p. 318), or neutrally as a tool useful to 'minimize 
liabilities and maximize opportunities" (Silvers, 2008, p. 22). It is worth emphasizing that the word 'risk' comes from the Latin word 'riscore', meaning dare, which means that it should be perceived as a conscious choice, not a necessity. However, it should also be noted that risk is often not fully realized (Appenzeller, 2005; Boo \& Gu, 2010). Running events' organizers carry risks that are both known and unknown to the administrator. While running events' directors have the responsibility to provide the safest conditions possible, participants have an equally important responsibility to ensure their own physical readiness to undertake such activity (Boo \& Gu, 2010; Fuller \& Drawer, 2004).

Sport events are carried out in conditions of uncertainty, which is due to internal and external factors (DSDM Consortium, 2010); however, there is ambiguity regarding the relation between risk and uncertainty. It happens that both terms are used interchangeably, but it can also be stated that uncertainty in the shorter periods takes the form of risk, or that 'the risk is a specific uncertainty' (DSDM Consortium, 2010, p.12). The ISO 31000 standard defines risk as the effect of uncertainty in pursuing a set goal (ISO 31000, 2018) and draws attention to the management of diversified risk. The standard also emphasizes the need for an individual approach to the definition adjustment as well as to the consideration of specific needs. Risk management includes context determination, risk assessment (including risk identification, analysis and evaluation) and risk treatment (ISO 31000, 2018).

In the literature on the event organization, risk management is often referred to as an action that aims at controlling the impact of unforeseen issues or accidents that take place within an event; thus, it is a proactive process (Ammon \& Brown, 2007; Hanstad, 2012; Leopkey \& Parent, 2009).

It is indicated that risk management in large-scale sporting events is becoming increasingly important and should be explored from different perspectives, as the holistic approach is recommended (Moyle et al., 2014; Leopkey \& Parent, 2009; Emery, 2010). However, governing bodies are the authorities that are majorly responsible for identifying and managing the risks associated with the event (Fuller \& Drawer, 2004). In Europe, the problem of the organization of large-scale running events and their risk assessment was rarely analyzed (Miśniakiewicz \& Łuczak, 2014; Kose, Argan \& Argan, 2011). Most papers on events risk management and reports on sport events risks come from the US, Canada and Australia (Appenzeller, 2005; Nohr, 2009; Leopkey\& Parent, 2009; Matheson, 2006).

Various studies have been conducted in the field of sport and sporting event risk management. The researchers have usually centered their interest on security and crowd control (Appenzeller, 2005; Giulianotti \& Klauser, 2010; Zoltak, 2001), injuries (Fuller \& Drawer, 2004; Hespanhol, Pena Costa \& Lopes, 2013), facility management (Preuss, 2007), effect of terrorism (Giulianotti \& Klauser, 2010; Toohey \& Taylor, 2008), actual losses caused by an event (Crompton, 1995) and lack of organizational planning (Getz, 2002). Special attention was paid to the overall impact of a sporting event on stakeholders (Leopkey \& Parent, 2009) and risk management strategies by stakeholders, as well as on practices (managers' profile, skills required and critical success factors) in sporting events (Emery, 2010). Different perspectives have been taken into account within risk management - the stakeholders in general (Leopkey \& Parent, 2009) and participants in particular (Hanstad, 2012; Fuller \& Drawer, 2004). Sporting event managers' attitude, beliefs and constraints have been also analyzed (Reid \& Ritchie, 2011).

Furthermore, risk issue categories by stakeholder groups have been identified (Leopkey \& Parent, 2009). The study provided the list of 14 risk issue categories important when dealing with risk management in sporting events: environmental, financial, human resources, infrastructure, interdependence, legacy, media, operations, organizing, participation, political, relationship, 
visibility and human resources. It was the starting point for the research on the assessment of risk management in largescale running events.

Until now, researchers were mostly focused on sporting events of international importance that were considered in the social, economic, promotional or planning context (Boo \& Gu, 2010; Toohey \& Taylor, 2008). There are few studies on events carried out for amateurs (i.e. Miśniakiewicz \& Łuczak 2014). The intention of the authors was to fill this gap. In the light of critical evaluations of the legitimacy of the organization of mega events - debatable social and financial benefits that most often demonstrate the legitimacy of their organization (Crompton, 1995; Preuss, 2007), it can be concluded that the smaller sporting events of national and local importance will be those that shall gain popularity in the future (Matheson, 2006).

\section{Methods}

The paper is based on the preparatory research (1) conducted in 2017 and the main research (2) conducted in 2017-2018. They aimed at identifying risk factors and estimating the risk related to organizing marathons (Table 1).

Table 1: Characteristics of the preparatory and the main study

\begin{tabular}{|l|l|l|}
\hline \multicolumn{1}{|c|}{ Preparatory research } & \multicolumn{1}{c|}{ Main research } \\
\hline $\begin{array}{l}\text { Research method, } \\
\text { conducted analyses }\end{array}$ & Delphi method & $\begin{array}{l}\text { Reliability analysis, risk } \\
\text { assessment; cluster analysis, } \\
\text { factor analysis }\end{array}$ \\
\hline Research tool & Discussed questionnaire & Questionnaire \\
\hline $\begin{array}{l}\text { Size of population } \\
\text { sample }\end{array}$ & 15 experts & $\begin{array}{l}\text { 31 representatives of 14 } \\
\text { marathons }\end{array}$ \\
\hline $\begin{array}{l}\text { Duration of } \\
\text { research }\end{array}$ & 2017 & 2017-2018 \\
\hline $\begin{array}{l}\text { Research objective } \\
\text { factors related to organizing } \\
\text { marathons. Preparation of the } \\
\text { proper research }\end{array}$ & $\begin{array}{l}\text { Risk assessment and analysis in } \\
\text { reference to organizing } \\
\text { marathons }\end{array}$ \\
\hline $\begin{array}{l}\text { IT tools, form of } \\
\text { research } \\
\text { realization }\end{array}$ & E-mail contact, meetings & e-risk app \\
\hline
\end{tabular}

Source: own research.

Within the preparatory research, the Delphi method (Thangaratinam \& Redman, 2005) was applied. The research involved fifteen experts in organizing long-distance runs. The experts were experienced participants (5), marathons organizers (5) and researchers in the areas of sports and project management (5).

The authors prepared a list of risk factors on the basis of the relevant professional literature (Leopkey \& Parent, 2009), own experience and legal requirements in Poland, and grouped them with the use of the Ishikawa diagram. The list of factors arranged in this form was sent via Internet to research participants, who shared their remarks, i.e. confirmed the validity of the included risk factors or considered them inadequate. They also proposed other factors and additional risk factor groups. After having taken participants' remarks into account, the material was sent again several times. The remarks were exchanged a few times (5-9) with most experts, which led to the modification of the factors list. These actions amounted to the basis of the research questionnaire.

The reliability analysis (Cronbach, 1951; Peterson, 1994) of the questionnaire was applied with the use of the Cronbach's alpha 
statistics to confirm the adequacy of the applied research instrument (Peterson, 1994). The Cronbach's alpha statistics result reached the level of 0.933 (21 positions). According to the classical interpretation, the coefficient should have the minimum value of 0.6 , whereas the preferable value of the coefficient is approx. 0.9. Thus, the internal cohesion of the research instrument was confirmed.

Within the main research, the agreed risk factors were evaluated on a scale ranging from 1 to 4 , according to their significance (impact) and probability of occurrence (Table 2).

Table 2: Characteristics of selected values in the proper research.

\begin{tabular}{|c|c|c|c|c|}
\hline Scale & \multicolumn{2}{|r|}{ Probability } & \multicolumn{2}{|r|}{ Impact } \\
\hline 1 & $\begin{array}{l}\text { Marginal } \\
\text { and low } \\
(0-30 \%)\end{array}$ & $\begin{array}{l}\text { - Risk will not occur or } \\
\text { will occur occasionally } \\
\text { - Expected number of } \\
\text { occurrences within a } \\
\text { period: less than } 1 \text { time } \\
\text { in } 5 \text { editions. }\end{array}$ & Insignificant & $\begin{array}{l}\text { Difficulty in realizing a } \\
\text { sporting event, which } \\
\text { influences its course } \\
\text { and objective } \\
\text { realization in an } \\
\text { insignificant way }\end{array}$ \\
\hline 2 & $\begin{array}{l}\text { Medium } \\
(31-60 \%)\end{array}$ & $\begin{array}{l}\text { - Risk occurrence is real, } \\
\text { but does not exceed } \\
60 \% \text {. } \\
\text { - } 1 \text { occurrence in the last } \\
\text { two editions. }\end{array}$ & Medium & $\begin{array}{l}\text { Clear and tangible } \\
\text { impact on the } \\
\text { organization and the } \\
\text { course of a sporting } \\
\text { event as well as the } \\
\text { realization of } \\
\text { objectives }\end{array}$ \\
\hline 3 & $\begin{array}{c}\text { High } \\
(61-80 \%)\end{array}$ & $\begin{array}{l}\text { - There are rational } \\
\text { premises that the risk } \\
\text { will materialize. } \\
\text { - It occurred once in the } \\
\text { last edition. }\end{array}$ & Large & $\begin{array}{l}\text { Significant impact on } \\
\text { the organization and } \\
\text { the course of a } \\
\text { sporting event as well } \\
\text { as the realization of } \\
\text { objectives, including } \\
\text { the ones related to } \\
\text { health. } \\
\text { Large impact on an } \\
\text { event's reputation }\end{array}$ \\
\hline 4 & $\begin{array}{l}\text { Very high } \\
(81-100 \%)\end{array}$ & $\begin{array}{l}\text { - There are rational } \\
\text { premises that the risk } \\
\text { will almost surely } \\
\text { materialize. } \\
\text { - In the last edition, it } \\
\text { occurred at least } 2 \\
\text { times. }\end{array}$ & $\begin{array}{c}\text { Very } \\
\text { significant }\end{array}$ & $\begin{array}{l}\text { Related to the health } \\
\text { and life of participants. } \\
\text { The necessity to } \\
\text { terminate the event. } \\
\text { No objectives are } \\
\text { achieved. }\end{array}$ \\
\hline
\end{tabular}

Source: own study based on ISO 31000.

The research was supported by the IT toolerisk (e-risk.pl). It allows for multidimensional configurability in reference to the methodology and risk factors. Moreover, it enables the full control of the activity of research participants. Three experienced representatives of selected marathons carried out the risk assessment. All fourteen analysed marathons were city runs held on flat or moderate terrains in Poland. Therefore, the events were similar in many aspects, e.g. climate conditions, participants' profile, the declared standard of organization, and legal regulations relevant to the organization process. 


\section{Research Results}

The research resulted in approving 75 risk factors divided into nine groups: Safety (1), Budget and finance (2), Information (3), Comfort and satisfaction of participants (4),
Organization (5), Start package (6), Recovery and energy support (7), Reputation (8), Environment and force majeure (9). Within each factor group, more specific risk factors were further indicated (Table 3).

Table 3: Groups and risk factors - the result of the preparatory research

\begin{tabular}{|c|c|c|}
\hline Group 1. Safety & Group 2. Budget and finance & Group 3. Information \\
\hline $\begin{array}{l}\text { 1.1. A serious accident on the } \\
\text { route } \\
\text { 1.2. An intrusion of a third party } \\
\text { onto the running route } \\
\text { 1.3. A participant with a poor } \\
\text { health condition } \\
\text { 1.4. A collision between people, } \\
\text { people and objects, etc. on } \\
\text { the running route } \\
\text { 1.5. A terrorist attack } \\
\text { 1.6. Intentional } \\
\text { pollution/spoilage of } \\
\text { food/beverages available } \\
\text { along the route/in the } \\
\text { finish zone } \\
\text { 1.7. Insufficient medical support }\end{array}$ & $\begin{array}{l}\text { 2.1. Insufficient income from } \\
\text { participants' fees } \\
\text { 2.2. Insufficient funding from } \\
\text { sponsors } \\
\text { 2.3. Insolvency } \\
\text { 2.4. Lack of profit at the planned } \\
\text { level } \\
\text { 2.5. Time overlapping with } \\
\text { another rival event } \\
\text { 2.6. Huge participation fees }\end{array}$ & $\begin{array}{l}\text { 3.1. Obsolete news on the website } \\
\text { 3.2. Lack of/insufficient contact } \\
\text { with potential participants } \\
\text { 3.3. Insufficient } \\
\text { promotion/information on } \\
\text { external websites } \\
\text { 3.4. Unintended disclosure of } \\
\text { personal data } \\
\text { 3.5. Personal data theft } \\
\text { 3.6. A cyber attack - modification, } \\
\text { blocking of the website } \\
\text { 3.7. Lack of a clear, interactive } \\
\text { map of the route } \\
\text { 3.8. Lack of early information } \\
\text { about the result }\end{array}$ \\
\hline $\begin{array}{l}\text { Group 4. Comfort and } \\
\text { satisfaction of participants }\end{array}$ & Group 5. Organization & Group 6. Start package and medal \\
\hline $\begin{array}{l}\text { 4.1. Lack of free accommodation } \\
\text { 4.2. Poor organization of the } \\
\text { deposit office } \\
\text { 4.3. Difficulty in reaching the } \\
\text { start line of the marathon } \\
\text { 4.4. Lack of parking spaces close } \\
\text { to the start zone } \\
\text { 4.5. Inability to receive start } \\
\text { packages on the day of } \\
\text { competition } \\
\text { 4.6. Mass start (not in waves) } \\
\text { 4.7. An inappropriately narrow } \\
\text { route, } \\
\text { 4.8. Lack of/unclear information } \\
\text { about the covered distance } \\
\text { 4.9. An unattractive route } \\
\text { 4.10. An unattractive expo, a } \\
\text { poorly-located expo } \\
\text { 4.11. Lack of access to showers } \\
\text { after the competition }\end{array}$ & $\begin{array}{l}\text { 5.1. Inappropriate running route } \\
\text { identification } \\
\text { 5.2. Insufficient access to toilets } \\
\text { 5.3. Unattractive catering at the } \\
\text { finish line } \\
\text { 5.4. Impossibility of gathering } \\
\text { spectators in the start and } \\
\text { finish zones } \\
\text { 5.5. Inappropriate organization } \\
\text { of the run - jams after the } \\
\text { beginning of the event } \\
\text { 5.6. Inappropriate organization } \\
\text { of the finish line } \\
\text { 5.7. Lack of the appropriate } \\
\text { atmosphere during the } \\
\text { event } \\
\text { 5.8. Problems related to } \\
\text { organization, time of the } \\
\text { event etc. by the local } \\
\text { community and the } \\
\text { administration } \\
\text { 5.9. Delayed starting time of the } \\
\text { event } \\
\text { 5.10. An unusually smaller } \\
\text { number of nutrition } \\
\text { points }\end{array}$ & $\begin{array}{l}\text { 6.1. An unattractive start package } \\
\text { 6.2. An unattractive design of the } \\
\text { medal } \\
\text { 6.3. An insufficient number of } \\
\text { medals } \\
\text { 6.4. An insufficient number of } \\
\text { start packages }\end{array}$ \\
\hline
\end{tabular}

Jacek Łuczak, Małgorzata Miśniakiewicz and Jose M. Saavedra, IBIMA Business Review, DOI: $10.5171 / 2021.178203$ 


\begin{tabular}{|c|c|c|}
\hline & $\begin{array}{l}\text { 5.11. Inappropriate organization } \\
\text { of nutrition points } \\
\text { 5.12. An insufficient number of } \\
\text { volunteers } \\
\text { 5.13. Lack of volunteers' } \\
\text { engagement } \\
\text { 5.14. Faulty time measurement } \\
\text { 5.15. Lack of established } \\
\text { procedures } \\
\text { 5.16. Limited human resources } \\
\text { 5.17. Incompatibility of the } \\
\text { running route capacity } \\
\text { with the number of } \\
\text { participants }\end{array}$ & \\
\hline $\begin{array}{l}\text { Group 7. Recovery and energy } \\
\text { support }\end{array}$ & Group 8. Reputation & $\begin{array}{l}\text { Group 9. Environment and force } \\
\text { majeure }\end{array}$ \\
\hline $\begin{array}{l}\text { 7.1. Lack of access to massage in } \\
\text { the finish zone } \\
\text { 7.2. Lack of the appropriate } \\
\text { hydration of participants } \\
\text { 7.3. An insufficient amount of } \\
\text { water at recovery points } \\
\text { 7.4. An insufficient number of } \\
\text { isotonic drinks at recovery } \\
\text { points } \\
\text { 7.5. An insufficient number of } \\
\text { energy gels, fruits etc. at } \\
\text { recovery points } \\
\text { 7.6. Random choice of } \\
\text { nutritional products at } \\
\text { recovery points and the } \\
\text { finish line } \\
\text { 7.7. Low health quality of the } \\
\text { offered nutritional and } \\
\text { recovery products } \\
\text { 7.8. Lack of the nutritional } \\
\text { awareness of participants } \\
\text { 7.9. Lack of nutritionists' } \\
\text { support } \\
\text { 7.10. Lack of/insufficient } \\
\text { number of cooling points } \\
\text { along the route }\end{array}$ & $\begin{array}{l}\text { 8.1. Unfavorable media } \\
\text { information on the national } \\
\text { scale } \\
\text { 8.2. Unfavorable media } \\
\text { information on the local } \\
\text { scale } \\
\text { 8.3. Lack of information about } \\
\text { the event in the national } \\
\text { media } \\
\text { 8.4. Lack of information about } \\
\text { the event in the local media } \\
\text { 8.5. An insufficient number of } \\
\text { participants } \\
\text { 8.6. A rival local event }\end{array}$ & $\begin{array}{l}\text { 9.1. Downpour } \\
\text { 9.2. Strong wind } \\
\text { 9.3. An overly low temperature } \\
\text { 9.4. An overly high temperature } \\
\text { 9.5. Difficult conditions of the } \\
\text { running route } \\
\text { 9.6. Traffic in the direct vicinity of } \\
\text { the event } \\
\text { 9.7. Force majeure }\end{array}$ \\
\hline
\end{tabular}
Source: own research.

Experts emphasized the importance of factors related to the physical safety of participants and organization. They also stressed risks linked with accidents on the route, bad health condition of participants, as well as terrorist and bioterrorist threats. Furthermore, personal data protection, especially compliance with GDPR, turned out to be significant. Experts clearly recognized the risk related to not assuring participants' satisfaction. In the questionnaire, they took account of issues linked with start packages, start organization, route attractiveness and deposit organization. Finally, the risk factors resulting from the preparatory research were used in the risk assessment conducted in the main research. 
The average values of risk factors were calculated considering the ones of the highest risk and the largest frequency. Five groups of risk factors were distinguished:

- $\quad$ Most significant (15) - the average value from 5.10 to 6.23 ,

- Less significant (21) - the average value from 4.14 to 4.94 ,

- Neutral (18) - the average value from 3.14 to 3.90 ,

- Of little significance (9) - the average value from 2.48 to 2.95 ,
- Insignificant (13) - the average value from 1.33 to 2.24 .

Respondents indicated the risk related to financing a marathon as the most significant one (insufficient income, profit at an unsatisfactory level, insolvency), followed by: organization (limited human resources, inappropriate organization, delayed start, incompatibility of the running route capacity with the number of participants), safety issues related to terrorist threats, cyber safety and participant's health condition (Table 4).

Table 4: The most significant and the less significant risk factors of organizing a marathon

\begin{tabular}{|c|c|c|c|c|}
\hline Code & The most significant risk factors & Average & Range & $\begin{array}{l}\text { Standard } \\
\text { deviation }\end{array}$ \\
\hline 2.2. & Insufficient funding from sponsors & 6.23 & 7.53 & 2.50 \\
\hline 5.16. & Limited human resources & 6.03 & 5.00 & 1.56 \\
\hline 5.8. & Problems related to organization & 6.01 & 7.50 & 2.35 \\
\hline 9.7. & Force majeure & 5.97 & 6.00 & 1.96 \\
\hline 2.5 . & Time overlapping with another rival event & 5.93 & 3.00 & 0.92 \\
\hline 5.6. & Inappropriate organization of the finish line & 5.92 & 6.00 & 1.67 \\
\hline 3.4 . & Unintended disclosure of personal data & 5.79 & 6.75 & 2.39 \\
\hline 5.14 & Faulty time measurement & 5.77 & 7.50 & 2.55 \\
\hline 2.1. & Insufficient income from participants' fees & 5.71 & 5.89 & 1.86 \\
\hline 6.3. & An insufficient number of medals & 5.71 & 4.50 & 1.45 \\
\hline 2.4 . & Lack of profit at the planned level & 5.27 & 7.00 & 2.13 \\
\hline 3.6. & A cyber attack - modification, blocking of the website & 5.26 & 6.75 & 2.34 \\
\hline 5.9. & Delayed starting time of the event & 5.26 & 3.44 & 1.00 \\
\hline 5.17. & $\begin{array}{l}\text { Incompatibility of the running route capacity and the } \\
\text { number of the participants }\end{array}$ & 5.17 & 5.50 & 1.69 \\
\hline 2.3. & Insolvency & 5.10 & 7.78 & 2.69 \\
\hline Code & Less significant risk factors & Average & Range & $\begin{array}{l}\text { Standard } \\
\text { deviation }\end{array}$ \\
\hline 6.1. & An unattractive start package & 4.94 & 4.50 & 1.54 \\
\hline 8.1. & Unfavorable media information on the national scale & 4.85 & 6.50 & 1.74 \\
\hline 4.5. & $\begin{array}{l}\text { Inability to receive start packages on the day of } \\
\text { competition }\end{array}$ & 4.79 & 6.89 & 1.99 \\
\hline 5.13. & \begin{tabular}{|l|} 
Lack of volunteers' engagement \\
\end{tabular} & 4.69 & 3.25 & 0.99 \\
\hline 5.5. & $\begin{array}{l}\text { Inappropriate organization of the run - jams after the } \\
\text { beginning of the event }\end{array}$ & 4.68 & 3.67 & 1.05 \\
\hline 9.1. & Downpour & 4.68 & 4.75 & 1.48 \\
\hline 3.5. & Personal data theft & 4.61 & 4.00 & 1.39 \\
\hline 8.5. & $\begin{array}{l}\text { An insufficient number of participants (too little } \\
\text { interest) }\end{array}$ & 4.56 & 6.00 & 1.79 \\
\hline 3.3. & $\begin{array}{l}\text { Insufficient promotion/information on external } \\
\text { websites }\end{array}$ & 4.53 & 4.25 & 1.40 \\
\hline 4.7. & An inappropriately narrow route & 4.51 & 4.50 & 1.57 \\
\hline
\end{tabular}




\begin{tabular}{|c|l|c|c|c|}
\hline 5.1. & Inappropriate running route identification & 4.41 & 5.00 & 1.74 \\
\hline 5.12. & An insufficient number of volunteers & 4.40 & 4.50 & 1.45 \\
\hline 9.4. & An overly high temperature & 4.37 & 5.25 & 1.64 \\
\hline 1.1 & A serious accident on the route & 4.36 & 3.25 & 1.14 \\
\hline 7.3. & An insufficient amount of water at recovery points & 4.35 & 5.00 & 1.72 \\
\hline 1.2 & An intrusion of a third party onto the running route & 4.23 & 3.75 & 1.21 \\
\hline 4.3. & Difficulty in reaching the start line of the marathon & 4.19 & 5.00 & 1.89 \\
\hline 4.2. & Poor organization of the deposit office & 4.17 & 2.50 & 0.92 \\
\hline 8.6. & A rival local event & 4.16 & 8.00 & 2.36 \\
\hline 1.5. & A terrorist attack (an explosion, shooting, ramming) & 4.15 & 6.00 & 1.89 \\
\hline 1.7. & Insufficient medical support & 4.14 & 5.50 & 1.55 \\
\hline
\end{tabular}

Source: own research.

These findings are found useful when focusing on specific factors and making organizational decisions. It can be observed that problems with funding and organization (limited human resources) are important. For participants and spectators likewise, it is a big festival; however, cyclical events disorganize the life of the local community. What is more, the substantial number of events and the season "limited" by the calendar often lead to a decrease in the number of participants due to rival marathons organized at the same time. It is worth noting that the importance of threats to the safety of participants and viewers, the risk of a terrorist attack, and the need to protect personal data are increasing nowadays (Lamont \& Kennelly, 2012; Toohey \& Taylor, 2008) as suggested by the obtained results.

\section{Conclusions}

The presented research has pioneered the systematic and methodological risk assessment of organizing large-scale running events, taking marathons held in Poland as an example. It may become a starting point for conducting further studies in reference to risk analysis and taking mitigation actions as well as examining their efficiency.

As a result, a database of risk factors (75) was developed regarding the organization of long-distance runs (marathons). Those factors were divided into separate groups (Security, Budget and Finances, Information, Comfort and Satisfaction of Participants, Organization, Starter Pack and Medal, Regeneration and Energy Support,
Reputation, Environment and Force Majeure).

After assessing the risk, taking into account the effect and the likelihood of a given factor, 5 groups of risk factors were identified (the most important, less important, neutral, not important and insignificant). The most important factors are related to the financing of marathons, organization issues, including the start date, the acceptance of the local community, the organization of the finish line, delayed starting time of the event, cyber security, disclosure of personal data, and problems with the measurement of time.

The research resulted in obtaining unequivocal data of risks on which mitigation actions should be centered. The risks are related to assuring funding for marathons, physical safety and personal data protection. The substantial number of marathons (and other sporting events) makes it extremely difficult to find such an event date that does not overlap with other runs and is favorable in the context of weather conditions. The most significant factors included threats leading to accidents on the route, which call for security measures, but also generally point to an insufficient number or lack of security services' engagement.

The research findings have led to the development of the elementary database of risk factors and the verification of the applied methodology (including the e-risk application). Moreover, the research may serve as a methodological source for any marathon organizer. 
The emerging industry of large-scale running events, as in the example of Poland shows, needs a mature approach to risk management. Although the "consideration of risk, only from the perspective of event organizers, is myopic" (Moyle et al., 2014, p. 102), there must be something to start with, as the organizers should "expect the best and prepare for the worst" (Moyle et al., 2014, pp.102-103). The risk assessment of marathons from the organizers' point of view seems to be a step in the right direction. Taking into account the perspective of a large-scale running event organizer, the analysis and evaluation of risks associated with the organization and execution can help develop more effective plans to minimize these threats. The most significant risks that should always be appraised by the management system were indicated in the study. If duly considered, they will surely help increase the security of mass participation races and the level of confidence of both organizers and participants.

\section{Disclosure Statement}

The authors reported no potential conflict of interest.

\section{References}

- Ammon R., Brown M. (2007).Risk management process, In: Law for recreation and sport managers (4 ed.), D.J. Cotten, J.T. Wolohan, J.T. (Eds.), Dubuque, IA: Kendall/ Hunt Publishing Company, 288-300.

- Appenzeller H., (2005). Risk Management (2nd ed.), Durham, NC: Carolina Academic Press.

- Boo S., Gu H., (2010). Risk perception of mega -events. Journal of Sport \& Tourism, 15(2), 139-161.

- Bowdin G., Allen J., O'Toole W., Harris R., McDonnell I. (2006). Events Management, Elsevier.

- Cronbach, L. J., (1951). Coefficient alpha and the internal structure of tests. Psychometrika. 16, 297-334.

- Crompton J.L., (1995). Economic impact analysis of sport facilities and events: Eleven sources of misapplication. Journal of Sport Management, 9(1), 14-35.

- DSDM Consortium, (2010), Agile Project Management. Handbook, Headley Brothers Limited, United Kingdom.

- Dzięgiel A., Lubowiecki-Vikuk A. P., (2013), Running Events as a Specific Type of Sporting Events, ZeszytyNaukowe. Turystyka i Rekreacja, 2(12), 119-135.

- Emery P., (2010).Past, present, future major sport event management practices: The practitioner perspective, Sport Management Review, 13, 158-170.

- Fuller C., Drawer S., (2004). The Application of Risk Management in Sport,Sports Medicina, 34(6), 349-356.

- Getz D., (2002). Why Events fail. Event Management, 7, 209-219.

- Giullianotti R., Klauser F., (2010). Security Governance and Sport Megaevents: Toward an Interdisciplinary Research Agenda.Journal of Sport and Social Issues, 34(1), 49-61.

- Hanstad D. V., (2012). Risk Management in Major Sporting Events: A Participating National Olympic Team's Perspective. Event Management, 16(3), 189-201.

- Hespanhol Jr L. C., Pena Costa L.O., Lopes A.D., (2013), Previous injuries and some training characteristics predict running-related injuries in recreational runners: a prospective cohort study, Journal of Physiotherapy, 59(4), 263-269.

- Hitchings R., Latham A., (2017), How 'social' is recreational running? Findings from a qualitative study in London and implications for public health promotion, Health\& Place, 46, 337-343.

- ISO 31000:2018, Risk management Principles and guidelines. International Standard Organisation.

- $\quad$ Kose H., Argan M. T., Argan M., (2011). Special Event management and event marketing: A case study of TKBL all star 2011 in Turkey, Journal of Management and Marketing Research, 8, 121-132.

- Lamont M., Kennelly M., 2012. A qualitative exploration of participant 
motives among committed amateur triathletes', Leisure Sciences, 34 (3), 236-255.

- $\quad$ Leopkey B., Parent M.M., (2009). Risk management issues in large-scale sporting events: A stakeholders' perspective. European Sport Management Quarterly, 9(2), 187-208.

- Matheson V., (2006). Mega-Events: The effect of the world's biggest sporting events on local, regional, and national economies, Economics Department Working Papers, College of the Holy Cross, CrossWorks, Worcester.

- $\quad$ Miller J., Pauline G., Wendt, J.T. (2013). An Investigation of Risk Management, Protocols at Triathlon Event, Journal of Venue \& Event Management, 4(2), 1734.

- Miśniakiewicz M., Łuczak J. (2014), Selected success factors of running events' organizers and participants, Selected Aspects of Quality and Environmental Management, Ed. by MałgorzataLotko, Jerzy Żuchowski, RyszardZieliński,

WydawnicwtoNaukoweInstytutuTech nologiiEksploatacji - PIB, Radom, p. 89-99.

- Moyle B., Kennelly M., Lamont M., (2014). Risk Management and Contingency Planning in Events: Participarnts' Reaction to the cancellation of Ironman New Zeeland 2012, International Journal of Event Management Research, 8(1), 94-106.

- $\quad$ Nohr K.M., (2009), Managing Risk in Sport and Recreation: The Essential Guide for Loss Prevention, Human Kinetics.

- $\quad$ Parent M.M.,

Séguin, B., (2007). Factors that led to the drowning of a world championship organizing committee: A stakeholder approach. European Sport Management Quarterly, 7(2), 187-212.
- $\quad$ Peterson R. A., (1994), A Meta-analysis of Cronbach's Coefficient Alpha, Journal of Consumer Research, 21(2), 381-391.

- Petridis, L., (2015). Greece: Mass Running: a New Trend from Ancient Times? In: Scheerder, J., Breedveld, K., Borgers, J. (Eds.), Running across Europe: The Rise and Size of One of the Largest Sport Markets. Palgrave Macmillan, Basingstoke, 140-162.

- Poland Runs. National Runner Survey[PolskaBiega, RaportNarodowySpisBiegaczy] (2014),on-line http://polskabiega.sport.pl/pdf/nsb_r aport.pdf, (Accessed 20 March 2016).

- Preuss H., (2007). The Conceptualization of Measurement of Mega Sport Event Legacies. Journal of Sport Tourism, 12(3), 207-228.

- Reid S., Ritchie B., (2011). Risk management: Event managers' attitudes, beliefs, and perceived constraints. Event Management, 15(4), 329-341.

- $\quad$ Scheerder, J., Breedveld, K., Borgers, J. (Eds.), (2015). Running Across Europe: The Rise and Size of One of the Largest Sport Markets. Palgrave Macmillan, London.

- Silvers (2008). Risk Management for Meetings and Events. New York, NY: Butterworth-Heinemann.

- Thangaratinam S. \& Redman C. W.E. (2005). The Delphi technique. Education. The Obstetrician \& Gynaecologist, 7, 120-125.

- Toohey K. \& Taylor T., (2008). Mega events, fear, and risk: Terrorism at the Olympic Games. Journal of Sport Management, 22, 451-469.

- ZoltakJ., (2001). Crowd control: When fans step over the line. Amusement Business. 113 (21), 22-24. 